medRxiv preprint doi: https://doi.org/10.1101/2019.12.16.19015024; this version posted December 19, 2019. The copyright holder for this preprint (which was not certified by peer review) is the author/funder, who has granted medRxiv a license to display the preprint in perpetuity.

It is made available under a CC-BY-NC-ND 4.0 International license .

\title{
A robust gene expression signature to predict proteasome inhibitor benefit in Multiple
} Myeloma

Joske Ubels1,2,3,4, Pieter Sonneveld3, Martin H. van Vliet4 and Jeroen de Ridder1,2*

1. Center for Molecular Medicine, University Medical Center Utrecht, Universiteitsweg 100, 3584 CG, Utrecht, The Netherlands 2. Oncode Institute, Utrecht, The Netherlands 3. Department of Hematology, Erasmus MC Cancer Institute, Wytemaweg 80, 3015 CN, Rotterdam, The Netherlands 4. SkylineDx, Lichtenaurlaan 40, 3062 ME, Rotterdam, The Netherlands

0 j.ubels@umcutrecht.nl ; p.sonneveld@erasmusmc.nl; m.vanvliet@skylinedx.com; j.deridder-

1 4@umcutrecht.nl

*corresponding author

Keywords: personalized medicine: gene expression signature; multiple myeloma; machine learning 
medRxiv preprint doi: https://doi.org/10.1101/2019.12.16.19015024; this version posted December 19, 2019. The copyright holder for this preprint (which was not certified by peer review) is the author/funder, who has granted medRxiv a license to display the preprint in perpetuity.

It is made available under a CC-BY-NC-ND 4.0 International license .

\section{Abstract}

17 Many cancer drugs only benefit a subset of the patients that receive them, but are often associated with serious side effects. Predictive classification methods that can identify which patients will benefit from a specific treatment are therefore of great clinical utility. We here

20 introduce a novel machine learning method to identify predictive gene expression signatures,

21 based on the idea that patients who received different treatments but exhibit similar expression

22 profiles can be used to model response to the alternative treatment. We use this method to

23 predict proteasome inhibitor benefit in Multiple Myeloma (MM). In a dataset of $910 \mathrm{MM}$ patients

24 we identify a 14-gene expression signature that can successfully predict benefit to the

25 proteasome inhibitor bortezomib, with a hazard ratio of $0.47(p=0.04)$ in class 'benefit', while in

26 class 'no benefit' the hazard ratio is $0.91(p=0.68)$. Importantly, we observe a similar

27 classification performance (HR class benefit $=0.46, p=0.04$ ) in an independent patient cohort

28 which was moreover measured on a different platform, demonstrating the robustness of the

29 signature. Moreover, we find that the genes in the discovered signature are essential, as no

30 equivalent signature can be found when they are excluded from the analysis. Multiple genes in

31 the signature are linked to working mechanisms of proteasome inhibitors or MM disease

32 progression. In conclusion, our method allows for identification of gene expression signatures

33 that can aid in treatment decisions for $\mathrm{MM}$ patients and provide insight into the biological

34 mechanism behind treatment benefit.

\section{Background}


medRxiv preprint doi: https://doi.org/10.1101/2019.12.16.19015024; this version posted December 19, 2019. The copyright holder for this preprint (which was not certified by peer review) is the author/funder, who has granted medRxiv a license to display the preprint in perpetuity.

It is made available under a CC-BY-NC-ND 4.0 International license .

38 For many anti-cancer drugs the response varies widely across patients. As many of these drugs

39 are associated with serious side effects, it is essential to identify which drug will maximally benefit

40 the patient. Tools that aid in such decisions, e.g. based on patient-derived genetic or

41 transcriptomic profiles have only been developed for a few treatments and diseases. Most efforts

42 in this direction focus on detecting specific mutations for which it is known that a targeted

43 therapy exists ${ }^{1}$. However, many patients do not carry any mutations that are known to be

44 actionable and in practice only $7 \%$ of patients can be matched to a targeted therapy with the

45 highest level of evidence ${ }^{2}$. Moreover, a range of efficacious therapies exist that are non-targeted

46 and can therefore not be matched to a specific mutation. Consequently, there is a clear clinical

47 utility for methods that can more generically predict - at the time of diagnosis - if a patient will

48 benefit from a certain treatment or not.

50 Multiple myeloma ( $\mathrm{MM}$ ) is characterized by a malignant proliferation of plasma cells, both in the

51 bone marrow and extramedullary sites. $\mathrm{MM}$ is considered incurable with a median survival of

52 approximately 6 years ${ }^{3}$. Several driver mutations have been identified in $\mathrm{MM}^{4}$, but in most

53 patients no actionable mutations are observed and targeted therapies are therefore not

54 commonly used in MM. Currently, proteasome inhibitors (PIs) are one of the most important

55 components of treatment in $\mathrm{MM}$ and since their introduction in the clinic survival has significantly

56 improved ${ }^{5}$. Since the immunoglobulin production of MM cells is higher than healthy plasma cells,

57 they are more reliant on proteasomal degradation of proteins, making them vulnerable to

58 proteasome inhibition ${ }^{6}$. After bortezomib, which was the first PI to be introduced in the clinic for 
medRxiv preprint doi: https://doi.org/10.1101/2019.12.16.19015024; this version posted December 19, 2019. The copyright holder for this preprint (which was not certified by peer review) is the author/funder, who has granted medRxiv a license to display the preprint in perpetuity.

It is made available under a CC-BY-NC-ND 4.0 International license .

$59 \mathrm{MM}$, second generation proteasome inhibitors like carfilzomib and ixazomib have recently been

60 approved.

61

62 Despite the success of PIs, there is still wide variability in PI response across patients. Substantial

63 efforts have been made to discover what distinguishes responders from non-responders. For

64 instance, several studies have implicated differential expression of genes involved in the

65 unfolded protein response ${ }^{7}$. Other studies describe complex changes in the entire energy

66 metabolism as a potential discriminating factor ${ }^{8}$. Several chromosomal aberrations have also

67 been found to influence bortezomib response, although this effect is still not fully understood

$68{ }^{9}, 10$. Despite all efforts, there is currently no biomarker capable of determining which patients will

69 benefit from receiving a $\mathrm{PI}$ and which would not.

71 Most of the studies investigating $\mathrm{PI}$ response compare gene expression patterns of patients

72 responding well or poor to a certain treatment ${ }^{7,11-13}$. The identified genes can then be combined

73 into a gene expression signature, which can be applied to classify newly diagnosed patients as

74 good or poor responders. However, a clinically more interesting question is whether a patient

75 will benefit more from a PI than from another treatment. This is a markedly different question

76 than identifying good and poor responders within one homogeneous treatment group. After all,

77 even patients with lower than average survival may still experience benefit from their treatment

78 as their outcome could have been even worse on another treatment. Conversely, a patient with

79 a good survival outcome, could have experienced an equivalently good or even better response

80 on any other treatment. As a result, it is impossible to assign patients to class 'benefit' or 'no 
medRxiv preprint doi: https://doi.org/10.1101/2019.12.16.19015024; this version posted December 19, 2019. The copyright holder for this preprint (which was not certified by peer review) is the author/funder, who has granted medRxiv a license to display the preprint in perpetuity.

It is made available under a CC-BY-NC-ND 4.0 International license .

81 benefit' a priori, since response to another treatment cannot be observed. Therefore, standard

82 methods of identifying gene signatures and classifiers, which rely on the existence of such class

83 labels, are unsuitable for predicting treatment benefit.

84

85 In this work we propose a novel method, Simulated Treatment Learning signatures (STLsig), to

86 infer gene signatures that can predict treatment benefit for patients at the moment of diagnosis.

87 We apply STLsig to find a gene expression signature capable of identifying patients for whom

88 treatment with PIs results in better survival than treatment with an alternative treatment. First

89 and foremost, the gene signature should be capable of predicting PI benefit in an independent

90 patient cohort, a feat which has been shown challenging for prognostic classifiers ${ }^{14}$. A second

91 important objective of STLsig is to identify a simple, interpretable model which contains genes

92 that have biological relevance to the molecular mechanism underlying PI efficacy. To enable this,

93 we leverage the core concept of Simulated Treatment Learning (STL), which we proposed

94 previously ${ }^{15}$, that allows training classifiers without having a predefined labelling of patient in e.g.

95 a class 'benefit' and 'no benefit'. However, while our previous method was successful in

96 identifying a model that can predict treatment benefit, these models rely on large numbers of

97 Gene Ontology sets together containing hundreds of genes. This makes interpretation of these

98 models complex. Moreover, many of the gene sets in the model can be removed without harming

99 performance, casting doubt on their importance in the molecular mechanism of PIs.

100

101 For these reasons we here propose a different approach which identifies small networks of genes

102 which can be used as a gene signature to predict PI benefit. To obtain a signature for treatment 
medRxiv preprint doi: https://doi.org/10.1101/2019.12.16.19015024; this version posted December 19, 2019. The copyright holder for this preprint (which was not certified by peer review) is the author/funder, who has granted medRxiv a license to display the preprint in perpetuity.

It is made available under a CC-BY-NC-ND 4.0 International license .

103 benefit, we aim to form gene networks that combine genes that are complementary in their

104 ability to predict benefit. STLsig achieves this by assessing the predictive ability of all possible

105 pairs of genes and only combining those that achieve a better performance together than when

106 combined with other genes. STLsig is fully data driven and does not rely on any biological

107 knowledge or predefined gene networks as input.

108

109 We demonstrate the utility of STLsig on a 910 sample dataset combining three different Phase III

110 clinical trials with MM patients receiving either a treatment with or without the PI bortezomib

111 (from here on referred to as the HTT cohort). STLsig enables discovery of a 14-gene signature

112 that can accurately identify a subset of patients benefiting from bortezomib. We validate this

113 gene expression signature in independent data (the CoMMpass cohort) where we predict benefit

114 for bortezomib or an alternative $\mathrm{PI}$, carfilzomib, demonstrating that the signature is robust and

115 generalizes to other data. Moreover, we established that the signature is unique, meaning that

116 when removed from the dataset no gene expression signature with a similar performance can be

117 found. The genes included in the signature are thus essential for predicting PI benefit. We find

118 that several of the genes in the signature are related to MM or the working mechanisms of PIs.

119 To our knowledge, this is the first approach capable of discovering treatment benefit specific

120 gene signatures without predefined labels.

121

\section{Results}

123

124 Overview of the algorithm 
medRxiv preprint doi: https://doi.org/10.1101/2019.12.16.19015024; this version posted December 19, 2019. The copyright holder for this preprint (which was not certified by peer review) is the author/funder, who has granted medRxiv a license to display the preprint in perpetuity.

It is made available under a CC-BY-NC-ND 4.0 International license .

125 STLsig relies on the idea that patients exhibiting similar gene expression profiles who received

126 different treatments, can be used to model response to the treatment they did not receive.

127 Similarity between patients needs to be defined by genes relevant to treatment benefit. STLsig

128 therefore derives treatment specific gene networks, which can be used to form a gene expression

129 signature capable of predicting treatment benefit. To train this signature we divide the HTT

130 cohort in a training set $(n=606)$ and a test set (Fold $D, n=304)$. The training set is further

131 subdivided into three equal parts, fold $A, B$ and $C$. We then assess the ability to predict

132 bortezomib benefit for all 5,506,221 gene pairs arising from the genes with a high variance across

133 patients pre-treatment in the HTT training set $(n=3319)$.

134 For each patient $j$ in fold $A$, we determine a z-score (zPFS) per gene pair describing the normalized

135 mean survival difference of patient $j$ with its most similar neighbours in terms of gene expression

136 that received a different treatment than patient $j$. The survival difference is normalized to obtain

137 a z-score by comparing it to the survival difference found with randomly selected neighbours. A

138 z-score above 0 indicates a larger positive survival difference than expected, a score below 0 a

139 smaller difference. We then test the ability of the gene pair to predict the zPFS score for patients

140 in fold B. We also assess the performance of each gene pair when calculation of zPFS is performed

141 on Fold B and predicted on Fold A. Performance of each gene pair is defined as the mean

142 Spearman rank correlation coefficient between predicted and calculated zPFS values in both

143 folds. A gene pair is retained if it is synergistic, i.e. if the genes in the pair predict zPFS better

144 together than when they are paired with other genes.

145 We next form a consensus network by repeating the two-fold cross validation five times. Only 146 gene pairs that are found to be synergistic in all repeats and that exceed the median correlation 
medRxiv preprint doi: https://doi.org/10.1101/2019.12.16.19015024; this version posted December 19, 2019. The copyright holder for this preprint (which was not certified by peer review) is the author/funder, who has granted medRxiv a license to display the preprint in perpetuity.

It is made available under a CC-BY-NC-ND 4.0 International license .

147 across all gene pairs and all repeats are retained. From this consensus network we extract gene

148 networks, i.e. all connected components.

150 A gene network can be used to classify patients by using its genes to recalculate a zPFS score for

151 each patient and classifying the top $25 \%$ of the patients as class 'benefit' and the rest as class 'no

152 benefit'. To evaluate each gene network, we use this procedure to classify all patients in fold A

153 and B. Subsequently, gene networks are ranked based on the difference between the Cox

154 regression $\beta$ 's found in class 'benefit' and class 'no benefit'. To build the signature, we

155 sequentially add each network based on this ranking and evaluate the performance of the

156 combined networks on fold $\mathrm{C}$. The different steps of the algorithm are summarized in Figure 1

157 and explained in detail in the Methods section.

159 Gene networks yield a 14-gene signature that can predict bortezomib benefit

160 The consensus network formed as described above contains 617 genes connected by 451 edges

161 and consists of 167 connected components, referred to as gene networks. Of these 167 gene

162 networks, 104 are individual gene pairs. The largest gene network contains 42 genes; the mean

163 number of genes per network is 3.7. We find that the optimal signature is formed by combining

164 the top two ranked gene networks, which are shown in Figure 2. Based on this signature we find

165 a hazard ratio (HR) of $0.49(\mathrm{p}=0.09,95 \% \mathrm{Cl} 0.22-1.11)$ in class 'benefit' $(n=50)$ and an HR of

$1660.91(p=0.74,95 \% \mathrm{Cl} 0.54-1.55)$ in class 'no benefit' $(n=152)$, on fold C of the HTT cohort. 
medRxiv preprint doi: https://doi.org/10.1101/2019.12.16.19015024; this version posted December 19, 2019. The copyright holder for this preprint (which was not certified by peer review) is the author/funder, who has granted medRxiv a license to display the preprint in perpetuity.

It is made available under a CC-BY-NC-ND 4.0 International license .

168 In clinical deployment of our classifier zPFS scores are not available, as survival of a patient is not

169 known at the moment of diagnosis. In order to assign a zPFS score to a new and unseen patient,

170 we calculate the distance in gene expression space between the new patient and every patient

171 in the training data, which we call the reference set. The predicted zPFS score of the new patient

172 is the weighted sum of the zPFS scores of the patients in the reference set. Weights are

173 determined by the inverse distance, i.e. more similar patients in the reference set contribute

174 most to the predicted zPFS for the new patient (see 'Methods' for details). In this manner, we

175 assess the ability of the 14-gene signature to predict benefit in unseen patients, using the 304

176 patients from the HTT cohort not included in training (Fold D). The HR in favour of bortezomib

177 found in the complete set of 304 patients is $0.75(p=0.11,95 \% \mathrm{Cl} 0.53-1.06)$. Figure 3a shows

178 the HR in class benefit obtained using different zPFS thresholds. This shows that a range of

179 thresholds result in an HR below the HR observed in the total dataset, indicating that the

180 predicted zPFS is associated with bortezomib benefit. The optimal class 'benefit', i.e. the class

181 'benefit' formed when we select the threshold associated with the lowest HR, comprises $30.6 \%$

182 of the patients which corresponds to a zPFS threshold of 0.326 . Using this threshold to define

183 class 'benefit' we find an HR of $0.47(p=0.04,95 \% \mathrm{Cl} 0.23-0.96)$ in class 'benefit' and an HR of

$1840.91(p=0.68,95 \% \mathrm{Cl} 0.60-1.39)$ in class 'no benefit' (figure $3 b)$. This establishes that our

185 signature can predict bortezomib benefit in unseen data from the same patient cohort,

186 demonstrating that the signature can be used prospectively to inform treatment choice. Our

187 results indicate that, despite the fact that nearly all MM patients receive a treatment regimen

188 that includes a $\mathrm{PI}^{5}$, approximately $70 \%$ of patients do not see benefit. 
medRxiv preprint doi: https://doi.org/10.1101/2019.12.16.19015024; this version posted December 19, 2019. The copyright holder for this preprint (which was not certified by peer review) is the author/funder, who has granted medRxiv a license to display the preprint in perpetuity.

It is made available under a CC-BY-NC-ND 4.0 International license .

190 The 14-gene signature achieves robust prediction performance in an independent patient cohort

191 Gene expression signatures often suffer from cohort-specific fitting and cross-validation within

192 one dataset can thus lead to an overestimation of performance ${ }^{16}$. To obtain a more robust

193 estimate of performance it is essential to perform validation on an external and completely

194 independent cohort. Therefore, to assess the robustness of our signature, we validate its

195 performance in the CoMMpass trial (NCT145429), which represents a completely independent

196 patient cohort which was moreover profiled on a different platform (RNAseq). In contrast to the

197 HTT dataset, which is a randomized clinical trial, the CoMMpass dataset is an observational study.

198 In this study there is no interference with treatment choice and the treatment regimens present

199 in this study thus represent current clinical practice in MM. To bring the CoMMpass RNAseq data

200 in the same space as the microarray reference dataset, we employ a ComBat batch correction

201 (Supplementary Figure 2 and Methods). In the HTT cohort, bortezomib is the only PI used, but In

202 the CoMMpass cohort, two different Pls are used: bortezomib and carfilzomib. To assess the

203 ability of the signature to predict PI benefit, we define a PI treatment arm $(n=686)$ and a no PI

204 treatment arm $(n=61)$. When we classify these patients with the 14-gene signature using the

205 threshold optimized on fold D from the HTT cohort, we find an HR of 0.46 ( $p=0.04,95 \% \mathrm{Cl} 0.22$

$206-0.97)$ in class 'benefit' $(n=150)$ and an HR of $0.79(p=0.2,95 \% \mathrm{Cl} 0.55-1.13)$ in class 'no

207 benefit' $(n=597$ ) (Figure 3c). Our signature is thus capable of predicting benefit in a completely 208 independent cohort and across platforms, indicating the signal picked up by our classifier is 209 robust and generalizes to the broader MM patient population. 
medRxiv preprint doi: https://doi.org/10.1101/2019.12.16.19015024; this version posted December 19, 2019. The copyright holder for this preprint (which was not certified by peer review) is the author/funder, who has granted medRxiv a license to display the preprint in perpetuity.

It is made available under a CC-BY-NC-ND 4.0 International license .

211 We next assess the performance of the signature for each of the two Pls separately. The majority

212 of the patients in the PI treatment arm received bortezomib $(n=530)$, while 156 patients received

213 carfilzomib. In the dataset as a whole an HR of $0.75(p=0.09,95 \% \mathrm{Cl} 0.54-1.04)$ in favor of

214 bortezomib is found, when compared with patients who did not receive a PI. An HR of 0.42 ( $p=$

$2150.0004,95 \% \mathrm{Cl} 0.26-0.68)$ is found in favor of carfilzomib. When we evaluate benefit for the

216 bortezomib patients only (excluding patients who received carfilzomib from the analysis), we find

217 an HR of $0.49(p=0.06,95 \% \mathrm{Cl} 0.23-1.03)$ in class 'benefit' $(n=124)$ and an HR of $0.84(p=0.35$,

$21895 \% \mathrm{Cl} 0.58-1.21)$ in class 'no benefit' $(n=467)$. When predicting benefit for the carfilzomib

219 patients only we find an HR of $0.31(p=0.06,95 \% \mathrm{Cl} 0.09-1.02)$ in class 'benefit' $(n=38)$ and an

$220 \mathrm{HR}$ of $0.45(p=0.004,95 \% \mathrm{Cl} 0.26-0.77)$ in class 'no benefit' $(n=178)$. These results confirm that

221 our signature is capable of identifying a patient group with more benefit than the population as

222 a whole for each of the Pls separately. Nonetheless it should be noted that the carfilzomib 'no

223 benefit' class should rather be considered a 'less benefit' class, as a significant HR in favor of

224 treatment with carfilzomib remains, likely due to the highly significant overall carfilzomib HR

225 (0.42). We could not train a carfilzomib specific classifier, as it was absent in the HTT cohort and

226 sample size in CoMMpass is insufficient. Nevertheless, the observation that the bortezomib

227 derived signature can identify a patient group with substantially reduced HRs for carfilzomib

228 treated patients indicates that it is more broadly applicable to PIs in general and not only

229 bortezomib.

230

231 We observed that the number of patients classified as 'benefit' in the CoMMpass dataset is 232 somewhat lower than on the HTT dataset $(20.1 \%$ of the patients compared to $30.6 \%$ of the 
medRxiv preprint doi: https://doi.org/10.1101/2019.12.16.19015024; this version posted December 19, 2019. The copyright holder for this preprint (which was not certified by peer review) is the author/funder, who has granted medRxiv a license to display the preprint in perpetuity.

It is made available under a CC-BY-NC-ND 4.0 International license .

233 patients in fold D of the HTT cohort). When we calculate the HR on the CoMMpass dataset using

234 different zPFS thresholds to define class 'benefit', we find that for both bortezomib and

235 carfilzomib the class 'benefit' associated with the lowest HR contains approximately $30 \%$ of the

236 patients (Figure 3d,e), similar to what was observed in the HTT data. These results show that zPFS

237 score is also associated with benefit at different zPFS thresholds and suggests approximately $30 \%$

238 of MM patients experience more benefit from PI treatment than the population as a whole.

240 Finally, we evaluated whether our model is specific to proteasome inhibitors and not more

241 generally predictive by testing its performance on lenalidomide, a drug with an

242 immunomodulatory mechanism. In the CoMMpass dataset, 411 patients received lenalidomide

243 and 336 did not (HR of 0.72 in favor of lenalidomide; $p=0.001,95 \% \mathrm{Cl} 0.58-0.88$ ). When we

244 define class 'benefit' according to the optimized zPFS threshold, $21.0 \%$ of patients are stratified

245 into the 'benefit' class. We find an HR of $0.80(p=0.35,95 \% \mathrm{Cl} 0.51-1.27)$ in class 'benefit' $(\mathrm{n}=$

$246150)$ and an HR of $0.68(p=0.001,95 \% \mathrm{Cl} 0.54-0.86)$ in class 'no benefit' $(n=467)$, hence not

247 improving the HR observed in the lenalidomide dataset as a whole. This clearly shows the 248 signature is predictive specifically for PIs.

250 Selected genes and links between them are essential for performance

251 In the setting of prognostic classification in breast cancer, it is well known that, after removal of

252 the genes in the prognostic signature, a new signature can be found containing a completely

253 different set of genes, that performs equal to the original signature ${ }^{17}$. This phenomenon casts

254 doubt on the value of interpreting the genes in the signature. If biological interpretation is the 
medRxiv preprint doi: https://doi.org/10.1101/2019.12.16.19015024; this version posted December 19, 2019. The copyright holder for this preprint (which was not certified by peer review) is the author/funder, who has granted medRxiv a license to display the preprint in perpetuity.

It is made available under a CC-BY-NC-ND 4.0 International license .

255 goal, it is therefore important that no equally performing signature without these genes can be

256 found.

257

258 We first investigate the importance of the individual genes in benefit prediction. This is achieved

259 by permuting the expression vector for each gene in the signature 100 times (while the other 13

260 genes remain unchanged) and using this signature with one permuted gene to predict class

261 'benefit' in fold D of the HTT cohort. Figure 4a shows the mean reduction in HR in class 'benefit'

262 after shuffling. These results indicate that each gene is important for the classification

263 performance. The largest effect is observed for DAB2IP, with a mean difference in validation HR

264 of 0.29 (se $=0.06$ ). We also note that correlation between genes influence the decrease in

265 performance. For instance, while shuffling SHTN1 has the smallest impact on validation

266 performance, its expression is significantly correlated with more genes than any other gene (with

267 TPD52L1, NES and ST6GAL2, see Supplementary figure 3 for correlation matrices), and therefore

268 losing its information in the signature is less impactful. Nevertheless, these results demonstrate

269 that all individual genes are important for the validation performance, as none can be shuffled

$270 \quad$ without decreasing performance.

271

272 Next, we assess whether the relation between the genes, as captured in the edges of the inferred

273 network, are important for classifier performance. To this end, we shuffle the edges between all

274 genes in the network, while ensuring every gene remains linked to at least one other gene, and

275 then infer a signature with STLsig. This procedure is repeated 10 times. The mean HR found in

276 the hold out data in class 'benefit' is 0.74 (se $=0.05$ ), which is approximately equal to the HR 
medRxiv preprint doi: https://doi.org/10.1101/2019.12.16.19015024; this version posted December 19, 2019. The copyright holder for this preprint (which was not certified by peer review) is the author/funder, who has granted medRxiv a license to display the preprint in perpetuity.

It is made available under a CC-BY-NC-ND 4.0 International license .

277 found in the dataset without classification. This shows that, in addition to the individual genes,

278 also their connections are essential for the performance of the signature.

279

280 Lastly, we remove all 14 genes contained in the signature from the dataset and search for a new

281 signature by rerunning the entire STLsig approach. The new signature, which contains 312 genes

282 from 85 gene networks, results in an HR of $0.56(p=0.23,95 \% \mathrm{Cl}=0.23-1.41)$ in the training

283 data. This is a much worse HR than the original 14-gene signature. Also, the performance on the

284 patients in the independent Fold D, which requires optimizing a new zPFS threshold, yields a

285 worse performance ( $\mathrm{HR}$ of $0.59 ; \mathrm{p}=0.06,95 \% \mathrm{Cl} 0.34-1.01 ; \mathrm{n}=130$ in the 'benefit' class).

286 Moreover, changing this threshold to yield a differently sized class 'benefit' does not yield

287 performances that approach that of the original 14-gene signature (Supplementary Figure 1).

289 Together, these results establish that the 14 identified genes are essential to the performance of

290 the model. This is an important prerequisite for interpretability of the model; as this indicates

291 that the 14 genes may play a functional role in the proteasome inhibitor response.

\section{Multiple signature genes are associated with MM or proteasome inhibition}

294 Having established the genes in the signature are essential to the performance, we investigate

295 how the genes in the signature are involved in determining PI benefit. Interestingly, in addition

296 to having the largest impact when its information is lost, DAB2IP is also the only gene that is

297 significantly differentially expressed between class 'benefit' and 'no benefit' $(p=0.002)$. DAB2IP

298 plays an essential role in the IRE1-mediated ER stress response and inducing apoptosis via the 
medRxiv preprint doi: https://doi.org/10.1101/2019.12.16.19015024; this version posted December 19, 2019. The copyright holder for this preprint (which was not certified by peer review) is the author/funder, who has granted medRxiv a license to display the preprint in perpetuity.

It is made available under a CC-BY-NC-ND 4.0 International license .

299 JNK pathway ${ }^{18}$. Apoptosis induced by ER-stress is one of the main working mechanisms of

300 proteasome inhibitors ${ }^{5}$.

301

302 None of the other signature genes are significantly differentially expressed between the classes

303 (Supplementary table 1). This lack of univariate association is to be expected, as our results show

304 that the combination of genes is essential for the benefit prediction. Several genes do have a

305 clear link to cancer or MM specifically. For instance, NES is a stem cell marker that is not found

306 in healthy plasma cells, but is found specifically in $\mathrm{MM}^{19}$. Moreover, NES has been associated

307 with treatment response in $\mathrm{MM}^{19}$. CLIP1 is involved in microtubule-kinetochore attachment and

308 plays a role in proper chromosome alignment during mitosis ${ }^{19,20}$ and has been associated with

309 cancer progression and chemotherapy resistance ${ }^{21}$, though not in relation to MM. SNX9 is

310 described to play an important role in trafficking ADAM9 to the cell surface ${ }^{22}$. ADAM9 is

311 expressed in MM cells and induces IL6 production by osteoblasts, potentially creating a more

312 permissive bone marrow environment for MM cell proliferation ${ }^{23}$. One of the described working

313 mechanisms of bortezomib is the downregulation of the production of IL-6 in the bone marrow

314 environment ${ }^{23,24}$. Some signature genes are also linked to the working of proteasome inhibitors.

315 The gene TPD52L1 is a negative regulator of ATM ${ }^{25}$, which is involved in the DNA damage

316 response and activated by bortezomib treatment ${ }^{25,26}$. ST6GAL2 has been described before to be

317 significantly downregulated in carfilzomib-resistant cell lines ${ }^{27}$. 
medRxiv preprint doi: https://doi.org/10.1101/2019.12.16.19015024; this version posted December 19, 2019. The copyright holder for this preprint (which was not certified by peer review) is the author/funder, who has granted medRxiv a license to display the preprint in perpetuity.

It is made available under a CC-BY-NC-ND 4.0 International license .

319 Together, this indicates that our signature is not only capable of identifying patients benefiting

320 from proteasome inhibitors, but also includes biologically relevant genes that aid in

321 understanding differential response to PI treatment.

322

323 Different cellular response to bortezomib in class benefit

324 For 142 patients in the HTT cohort tumor gene expression was measured again 48 hours after

325 receiving bortezomib. To investigate whether the cellular response to bortezomib is different for

326 patients classified as 'benefit', we performed a differential expression analysis between the gene

327 expression before and after treatment separately in class 'benefit' and class 'no benefit' using

328 SAM $^{28}$. Because the number of patients in class 'benefit' for which a second measurement is

329 available is small, we relaxed our definition of benefit and stratify the patients into the 'benefit'

330 class if the calculated zPFS >0 and to the 'no benefit' class otherwise. This results in 71 out of 142

331 patients being classified as benefiting. We find 12 genes that are significantly differentially

332 expressed before and after treatment in class 'benefit' but not in class 'no benefit'. We also find

333 two genes that are significantly differentially expressed only in class 'no benefit'. These 14

334 differentially expressed genes and their mean fold change after treatment are shown in figure

335 4c. To identify the genes that truly represent a different cellular response in class 'benefit' and

336 'no benefit', we compute the difference in fold change between both classes. To ensure that this

337 is not a random difference, we also compute this difference for all genes using 1000 random class

338 labellings. We find four genes - TNS3, PXN, C2CD4A and PSPC1 - where the difference between

339 'benefit' and 'no benefit' is larger than expected by random chance $(p<0.05$ after Bonferroni

340 correction for multiple testing). None of these genes have been described in the context of MM, 
medRxiv preprint doi: https://doi.org/10.1101/2019.12.16.19015024; this version posted December 19, 2019. The copyright holder for this preprint (which was not certified by peer review) is the author/funder, who has granted medRxiv a license to display the preprint in perpetuity.

It is made available under a CC-BY-NC-ND 4.0 International license .

341 though all have been connected to disease progression in other cancer types ${ }^{29}, 30,31,32$. More

342 interestingly, TNS3, PXN and PSPC1 are all described to play a role in cell adhesion and a migratory

343 phenotype ${ }^{33}, 32$. Cell adhesion mediated drug resistance (CAM-DR) has been described

344 extensively in $\mathrm{MM}^{34}, 35,36$. Moreover, it has been suggested that bortezomib can overcome CAM-

$345 \mathrm{DR}^{37}, 38$. A different regulation of cell adhesion in class 'benefit' could play a role in the observed

346 benefit to PIs.

\section{Discussion}

350 In this work we propose STLsig, a method to identify interpretable signatures that robustly

351 predict patient benefit to PIs from a gene expression measurement at time of diagnosis. The 14

352 gene signature, derived with our method, validates on an independent patient cohort which was

353 moreover measured on a different platform, confirming the robust nature of the signature.

355 Pls play a major role in MM treatment today. Yet our results indicate that many patients do not

356 benefit from PI treatment and better selection of patients that do benefit is crucial. The signature

357 identified here has direct applicability in the clinic to aid in optimal treatment selection.

359 One of the main aims of constructing simple gene expression signatures is that the genes in the

360 signature may provide insight into the underlying biology. Interpreting the signature is, however,

361 only meaningful if the genes in the signature are essential and unique. Our signature adheres to

362 both these properties as substantial drop in performance is observed when one of the genes in

363 the signature is shuffled and no similar signature can be found when the original 14 genes are 
medRxiv preprint doi: https://doi.org/10.1101/2019.12.16.19015024; this version posted December 19, 2019. The copyright holder for this preprint (which was not certified by peer review) is the author/funder, who has granted medRxiv a license to display the preprint in perpetuity.

It is made available under a CC-BY-NC-ND 4.0 International license .

364 excluded from the analysis. These findings reinforce the importance of the selected genes and

365 indicate the power of STLsig to further elucidate proteasome inhibitor specific mechanisms.

367 Several of the genes in the signature are already described to be involved in the proteasome

368 system or disease progression in MM. For instance, genes involved in the unfolded protein

369 response have been described before to play a role in bortezomib response ${ }^{39}$. The fact that our

370 data-driven approach selects genes also involved in this process, indicates we can capture biology

371 without inserting biological knowledge into the model beforehand. Therefore, we propose that

372 the genes in our signature not yet described in the literature to be involved in PI efficacy, may

373 have an as of yet undiscovered role in determining proteasome inhibitor benefit and are

374 interesting targets for further research.

376 We found that our classifier, which was trained on bortezomib, also performed well in predicting

377 benefit to another $\mathrm{PI}$, carfilzomib. This is impressive as the model had no opportunity to learn

378 carfilzomib-specific mechanisms. Although a carfilzomib signature that can be used in the clinic

379 would need more specific optimization, our results do indicate that at least some sensitivity

380 mechanisms overlap between bortezomib and carfilzomib.

382 STLsig can readily be applied to other diseases and drugs. A very potent application could be to 383 perform post-hoc analysis of clinical trial data for drugs which missed their endpoint. Such 384 analysis could reveal a subset of patients who would still benefit from the drug, thus potentially 385 extracting extremely valuable information from failed clinical trials. 
medRxiv preprint doi: https://doi.org/10.1101/2019.12.16.19015024; this version posted December 19, 2019. The copyright holder for this preprint (which was not certified by peer review) is the author/funder, who has granted medRxiv a license to display the preprint in perpetuity.

It is made available under a CC-BY-NC-ND 4.0 International license .

387 Taken together, we provide a powerful machine learning approach to aid in treatment decisions

388 in the clinic, ensuring a more optimal treatment choice and ultimately improve patient outcomes.

390 Methods

391 Data

392 To develop the gene network and train the bortezomib benefit signature, we pool gene

393 expression and survival data from three phase III trials (referred to as the HTT cohort): Total

394 Therapy $2\left(\right.$ TT2, GSE2658) $^{40}$, Total Therapy $3\left(\right.$ TT3, GSE2658) ${ }^{40}$ and HOVON-65/GMMG-HD4

$395\left(\right.$ H65, GSE19784) ${ }^{41}$. The TT2 dataset includes 345 newly diagnosed multiple myeloma 396 (NDMM) samples, treated either with thalidomide and melphalan ( $n=173$ ) or melphalan

397 alone $(n=172)$. The TT3 dataset includes 238 NDMM samples treated with bortezomib,

398 thalidomide, dexamethasone, cyclophosphamide, cisplatin and etoposide (VTDPACE). The

399 H65 dataset includes 327 NDMM samples, treated either with vincristine, doxorubicin and

400 dexamethasone (VAD, $n=158)$ or bortezomib, doxorubicin and dexamethasone $(P A D, n=$

401 169). In our analyses of the pooled data two treatment arms are considered: a bortezomib

402 arm, which comprises the PAD arm from H65 and TT3, and a non-bortezomib arm, which

403 comprises the VAD arm from H65 and TT2. Combined, these datasets form the HTT cohort

404 and include 910 patients, of which 407 received bortezomib and 503 did not. Of these 910,

405606 are used as HTT training data and 304 as HTT hold out data. 
medRxiv preprint doi: https://doi.org/10.1101/2019.12.16.19015024; this version posted December 19, 2019. The copyright holder for this preprint (which was not certified by peer review) is the author/funder, who has granted medRxiv a license to display the preprint in perpetuity.

It is made available under a CC-BY-NC-ND 4.0 International license .

407 All samples have been profiled with the Affymetrix Human Genome U133 plus 2.0 array.

408 Gene expression is MAS5 and log2 normalized. Batch effects resulting from pooling different 409 datasets are corrected with ComBat ${ }^{42}$. Data is scaled to mean 0 and variance 1 per probeset.

411 For validation of both the bortezomib model and carfilzomib model, we use the CoMMpass 412 trial (NCT0145429) dataset generated by the Multiple Myeloma Research Foundation

413 (MMRF). For 747 patients both RNAseq, survival data, and treatment information is available

414 (CoMMpass Interim Analysis 13). Of these patients, 61 did not receive any PI in first line 415 treatment, 530 received bortezomib and 156 received carfilzomib. Sequencing data is 416 processed with the Cufflinks pipeline (for details see researcher.themmrf.org). For validation 417 we combine the log2 normalized values from the HTT data and the FPKM values from 418 CoMMpass. We scale the combined data to mean 0 and variance 1 and then perform ComBat 419 batch correction, as performing mean-variance scaling before ComBat leads to better 420 overlap between the datasets in the tSNE. In ComBat batch correction H65, TT2, TT3 and 421 CoMMpass are defined as four separate batches.

423 For all survival analyses, we use Progression Free Survival (PFS) as an endpoint. Cox 424 proportional hazard models were fitted using the R package 'survival' (version 2.44). All HRs 425 are computed as PI vs no PI, which means a HR below 1 signifies a benefit from the 426 treatment. For the survival analysis in the HTT cohort we stratify for dataset of origin, to 427 correct for the significant survival difference between the Total Therapy dataset and the 428 Hovon65/GMMG-HD 4 dataset. 
medRxiv preprint doi: https://doi.org/10.1101/2019.12.16.19015024; this version posted December 19, 2019. The copyright holder for this preprint (which was not certified by peer review) is the author/funder, who has granted medRxiv a license to display the preprint in perpetuity.

It is made available under a CC-BY-NC-ND 4.0 International license.

431 We select only probe sets that meet the following requirements: (i) variance across the samples

$432>2$ in the training dataset before mean variance scaling, (ii) unambiguous mapping to one gene

433 and (iii) matching gene in the CoMMpass dataset. This yields $n=3319$ genes. We then construct

434 all possible gene pairs from these 3319 genes, resulting in 5,506,221 gene pairs.

436 To train the gene signature we divide the HTT cohort $(n=910)$ into four folds, Fold A $(n=202)$,

437 Fold $B(n=202)$, Fold $C(n=202)$ and Fold $D(n=304)$. Fold $A, B$ and $C$ are used to train the

438 signature as described below, while fold D acts as hold out data to validate the signature and 439 optimize a threshold to use in independent validation data.

441 To determine treatment benefit, we follow the core concept of STL laid out in our previous work ${ }^{3}$,

442 where for each patient a score zPFS is defined that measures whether the patient survived longer

443 than expected compared to patients with similar gene expression that received another

444 treatment. More specifically, for genepair $\{n, m\}$ and patient $j$ we define:

$$
\mu P F S_{j}^{n, m}=\frac{I}{K} \sum_{i \in \Pi^{j}} P F S_{j}-P F S_{i}
$$

446 where $\mathrm{PFS}_{\mathrm{j}}$ is the progression free survival time of patient $j, \mathrm{l}=1$ if patient $\mathrm{j}$ received the target

447 treatment (a PI in this work) and $\mathrm{I}=-1$, otherwise. Moreover, $\Pi^{j}$ the set of $\mathrm{K}$ nearest neighbors to

448 patient $\mathrm{j}$ defined in terms of euclidean distance in the expression space spanned by genes $\mathrm{n}$ and

$449 \mathrm{~m}$ and only considering patients that received another treatment than patient $\mathrm{j}$. Throughout this 
medRxiv preprint doi: https://doi.org/10.1101/2019.12.16.19015024; this version posted December 19, 2019. The copyright holder for this preprint (which was not certified by peer review) is the author/funder, who has granted medRxiv a license to display the preprint in perpetuity.

It is made available under a CC-BY-NC-ND 4.0 International license .

450 manuscript $\mathrm{K}=10$. In the set $\Pi^{j}$, we discard patients for whom we cannot be sure whether they

451 survived longer or not (i.e. if both patients are censored). This leads to an average of 7 patients

452 being used in the calculation of $\mu \mathrm{PFS}_{\mathrm{j}}$. Subsequently, $z \mathrm{PFS}$ is normalized to a $z$-score by comparing

$453 \mu \mathrm{PFS}$ to a background distribution resulting from repeating this procedure $\mathrm{M}=1000$ times with a

454 random $\Pi^{j}$. The zPFS score describes how much smaller (or larger) the survival of patient $j$ is

455 compared to patients with similar gene expression but opposite treatment than expected by

456 random chance.

457

458 To score gene pairs, a 2 -fold cross validation is employed using fold $A(n=202)$ and fold $B(n=$

459 202). Within each fold, a $\mathrm{kNN}$-regression model $(\mathrm{k}=10)$ is trained, which is used to predict zPFS

460 on the other fold. The gene pair score is defined as the Spearman correlation coefficient between

461 the predicted zPFS and calculated zPFS across all patients. The score for each gene pair is the

462 mean correlation of the 2 folds. We repeat this procedure 5 times with a different split in folds.

464 Gene network construction

465 We construct gene networks separately for all 5 repeats and then construct a consensus network,

466 which only contains the genes and edges found in all 5 repeats. To construct the gene networks,

467 for each gene, we rank all gene pairs containing that gene on the mean Spearman correlation

468 coefficient found. We then connect genes that are mutually synergistic, i.e. gene A should be

469 among gene $B$ 's best partners and vice versa. We achieve this by requiring that $A B$ is among the

470 top $5 \%$ of pairs including A and among the top $5 \%$ of pairs including B. However, if a single gene

471 is informative for treatment benefit, gene pairs containing this gene could be highly ranked even 
medRxiv preprint doi: https://doi.org/10.1101/2019.12.16.19015024; this version posted December 19, 2019. The copyright holder for this preprint (which was not certified by peer review) is the author/funder, who has granted medRxiv a license to display the preprint in perpetuity.

It is made available under a CC-BY-NC-ND 4.0 International license .

472 if the second gene is uninformative. Including these gene pairs in our network and subsequent

473 signature would introduce noise, which would both harm biological interpretation of the

474 signature and potentially decrease the predictive performance in independent data. Therefore,

475 we also require the mean correlation of the gene pair to be above the median correlation of all

476 selected gene pairs. We evaluate all gene networks in the consensus network on their ability to

477 predict benefit and select the best performing combination to construct the signature.

478

479 Gene network selection and gene signature construction

480 After gene network construction, gene networks are selected using forward feature selection. To

481 rank gene networks, we determine the predictive performance for each gene network. To this

482 end, we calculate zPFS for each patient and each gene network separately on fold A and B

483 together ( $n=404)$. The top $25 \%$ of patients (in terms of zPFS) are assigned to class 'benefit', while

484 the remaining patients are assigned to class 'no benefit'. Subsequently, A Cox proportional

485 hazards regression on the treatment variable is performed within the 'benefit' patient group as

486 well as in the 'no benefit' patients. The performance of a gene network is defined by the

487 difference between the Cox' regression $\beta$ 's in class 'benefit' and class 'no benefit'.

488 To select gene networks to use in the final model we perform forward feature selection using

489 fold C, which comprises 202 patients not used in fold A and B. Gene networks are added

490 sequentially based on their performance on fold A and B. Ranking of patients across more than

491 one gene network is done based on the sum of the zPFS scores of the individual gene networks.

492

$493 \quad$ Validation of gene networks 
medRxiv preprint doi: https://doi.org/10.1101/2019.12.16.19015024; this version posted December 19, 2019. The copyright holder for this preprint (which was not certified by peer review) is the author/funder, who has granted medRxiv a license to display the preprint in perpetuity.

It is made available under a CC-BY-NC-ND 4.0 International license .

494

495 To validate the signature in independent data, we use all training data $(n=606)$ as a reference

496 set where zPFS is known. For each patient in the validation set we compute the euclidean

497 distance to all patients in the reference set per gene network. We then use inverse distance

498 weighting to calculate the estimated zPFS of a validation patient $j$ by

499

$$
\widehat{z F S}_{\jmath}=\frac{\sum_{i \in T} w_{i} * z P F S_{i}}{\sum_{i \in T} w_{i}}
$$

500 where $T$ comprises all patients in the reference dataset. Given a certain gene expression vector

$501 \quad x$, weights $w_{i}$ are given by

502

$$
w_{i}=\frac{1}{d\left(x_{j}, x_{i}\right)}
$$

503 where $d$ is the Euclidean distance between the expression data of gene $\mathrm{x}$ of patients $\mathrm{i}$ and $\mathrm{j}$.

504

505 References

506

507 1. Syn, N. L.-X., Yong, W.-P., Goh, B.-C. \& Lee, S.-C. Evolving landscape of tumor molecular

508 profiling for personalized cancer therapy: a comprehensive review. Expert Opin. Drug

$509 \quad$ Metab. Toxicol. 12, 911-922 (2016).

510 2. Zehir, A. et al. Mutational landscape of metastatic cancer revealed from prospective clinical

511 sequencing of 10,000 patients. Nat. Med. 23, 703-713 (2017).

512 3. Rajkumar, S. V. \& Vincent Rajkumar, S. Multiple myeloma: 2018 update on diagnosis, risk-

513 stratification, and management. American Journal of Hematology vol. 93 1091-1110 
medRxiv preprint doi: https://doi.org/10.1101/2019.12.16.19015024; this version posted December 19, 2019. The copyright holder for this preprint (which was not certified by peer review) is the author/funder, who has granted medRxiv a license to display the preprint in perpetuity.

It is made available under a CC-BY-NC-ND 4.0 International license .

514

(2018).

515 4. Walker BA, Mavrommatis K, Wardell CP, et al. Identification of novel mutational drivers 516 reveals oncogene dependencies in multiple myeloma. 2018;132(6):587-597. Blood 132, $517 \quad 1461(2018)$.

518 5. Moreau, P. et al. Proteasome inhibitors in multiple myeloma: 10 years later. Blood 120, 519 947-959 (2012).

520 6. Laubach, J., Richardson, P. \& Anderson, K. Multiple myeloma. Annu. Rev. Med. 62, 249-264 (2011).

522

7. Dong, H. et al. Dysregulation of unfolded protein response partially underlies proapoptotic activity of bortezomib in multiple myeloma cells. Leuk. Lymphoma 50, 974-984 (2009).

8. Soriano, G. P. et al. Proteasome inhibitor-adapted myeloma cells are largely independent from proteasome activity and show complex proteomic changes, in particular in redox and energy metabolism. Leukemia 30, 2198-2207 (2016).

9. Smetana, J. et al. Gain(1)(q21) is an Unfavorable Genetic Prognostic Factor for Patients With Relapsed Multiple Myeloma Treated With Thalidomide but Not for Those Treated With Bortezomib. Clinical Lymphoma Myeloma and Leukemia vol. 13 123-130 (2013).

10. Avet-Loiseau, H. et al. Use of bortezomib to overcome the poor prognosis of $t(4 ; 14)$, but not del(17p), in young patients with newly diagnosed multiple myeloma. Journal of Clinical Oncology vol. 28 8113-8113 (2010).

11. Hofman, I. J. F. et al. RPL5 on 1p22.1 is recurrently deleted in multiple myeloma and its

535 12. Yoshida, T. et al. Low expression of neural cell adhesion molecule, CD56, is associated with 
medRxiv preprint doi: https://doi.org/10.1101/2019.12.16.19015024; this version posted December 19, 2019. The copyright holder for this preprint (which was not certified by peer review) is the author/funder, who has granted medRxiv a license to display the preprint in perpetuity.

It is made available under a CC-BY-NC-ND 4.0 International license .

low efficacy of bortezomib plus dexamethasone therapy in multiple myeloma. PLoS One 13, e0196780 (2018).

13. Narita, T. et al. Lower expression of activating transcription factors 3 and 4 correlates with shorter progression-free survival in multiple myeloma patients receiving bortezomib plus dexamethasone therapy. Blood Cancer J. 5, e373 (2015).

14. Bernau, C. et al. Cross-study validation for the assessment of prediction algorithms. Bioinformatics 30, i105-12 (2014).

15. Ubels, J. et al. Predicting treatment benefit in multiple myeloma through simulation of alternative treatment effects. Nat. Commun. 9, 2943 (2018).

16. Castaldi, P. J., Dahabreh, I. J. \& loannidis, J. P. A. An empirical assessment of validation practices for molecular classifiers. Brief. Bioinform. 12, 189-202 (2011).

17. Ein-Dor, L., Kela, I., Getz, G., Givol, D. \& Domany, E. Outcome signature genes in breast cancer: is there a unique set? Bioinformatics 21, 171-178 (2005).

18. Luo, D. et al. AIP1 is critical in transducing IRE1-mediated endoplasmic reticulum stress response. J. Biol. Chem. 283, 11905-11912 (2008).

19. Svachova, H. et al. Nestin expression throughout multistep pathogenesis of multiple myeloma. Br. J. Haematol. 164, 701-709 (2014).

20. Amin, M. A., Itoh, G., lemura, K., Ikeda, M. \& Tanaka, K. CLIP-170 recruits PLK1 to kinetochores during early mitosis for chromosome alignment. J. Cell Sci. 127, 2818-2824 (2014).

21. Sun, X. et al. Microtubule-binding protein CLIP-170 is a mediator of paclitaxel sensitivity. J. Pathol. 226, 666-673 (2012). 
medRxiv preprint doi: https://doi.org/10.1101/2019.12.16.19015024; this version posted December 19, 2019. The copyright holder for this preprint (which was not certified by peer review) is the author/funder, who has granted medRxiv a license to display the preprint in perpetuity.

It is made available under a CC-BY-NC-ND 4.0 International license.

22. Mygind, K. J. et al. Sorting nexin 9 (SNX9) regulates levels of the transmembrane ADAM9 at the cell surface. J. Biol. Chem. 293, 8077-8088 (2018).

23. Karadag, A., Zhou, M. \& Croucher, P. I. ADAM-9 (MDC-9/meltrin- - ), a member of the adisintegrin and metalloproteinase family, regulates myeloma-cell-induced interleukin-6 production in osteoblasts by direct interaction with the avß5 integrin. Blood vol. 107 32713278 (2006).

24. Roccaro, A. M. et al. Bortezomib mediates antiangiogenesis in multiple myeloma via direct and indirect effects on endothelial cells. Cancer Res. 66, 184-191 (2006).

25. Chen, Y. et al. Tumor protein D52 represents a negative regulator of ATM protein levels. Cell Cycle 12, 3083-3097 (2013).

26. Hideshima, T. et al. Molecular mechanisms mediating antimyeloma activity of proteasome inhibitor PS-341. Blood 101, 1530-1534 (2003).

27. Zheng, Z., Liu, T., Zheng, J. \& Hu, J. Clarifying the molecular mechanism associated with carfilzomib resistance in human multiple myeloma using microarray gene expression profile and genetic interaction network. Onco. Targets. Ther. 10, 1327-1334 (2017).

28. Tusher, V. G., Tibshirani, R. \& Chu, G. Significance analysis of microarrays applied to the ionizing radiation response. Proceedings of the National Academy of Sciences vol. 98 51165121 (2001).

29. Carter, J. A., Górecki, D. C., Mein, C. A., Ljungberg, B. \& Hafizi, S. CpG dinucleotide-specific hypermethylation of the TNS3 gene promoter in human renal cell carcinoma. Epigenetics 8 , 739-747 (2013).

30. Wu, D.-W. et al. Paxillin Predicts Survival and Relapse in Non-Small Cell Lung Cancer by 
medRxiv preprint doi: https://doi.org/10.1101/2019.12.16.19015024; this version posted December 19, 2019. The copyright holder for this preprint (which was not certified by peer review) is the author/funder, who has granted medRxiv a license to display the preprint in perpetuity.

It is made available under a CC-BY-NC-ND 4.0 International license .

MicroRNA-218 Targeting. Cancer Research vol. 70 10392-10401 (2010).

31. Yao, F., Zhang, C., Du, W., Liu, C. \& Xu, Y. Identification of Gene-Expression Signatures and Protein Markers for Breast Cancer Grading and Staging. PLoS One 10, e0138213 (2015).

32. Yeh, H.-W. et al. PSPC1 mediates TGF- $\beta 1$ autocrine signalling and Smad2/3 target switching to promote EMT, stemness and metastasis. Nat. Cell Biol. 20, 479-491 (2018).

33. Mouneimne, G. \& Brugge, J. S. Tensins: a new switch in cell migration. Dev. Cell 13, 317319 (2007).

34. Damiano, J. S., Cress, A. E., Hazlehurst, L. A., Shtil, A. A. \& Dalton, W. S. Cell adhesion mediated drug resistance (CAM-DR): role of integrins and resistance to apoptosis in human myeloma cell lines. Blood 93, 1658-1667 (1999).

35. Landowski, T. H., Olashaw, N. E., Agrawal, D. \& Dalton, W. S. Cell adhesion-mediated drug resistance (CAM-DR) is associated with activation of NF-kappa B (RelB/p50) in myeloma

36. Damiano, J. S. \& Dalton, W. S. Integrin-mediated drug resistance in multiple myeloma. Leuk. Lymphoma 38, 71-81 (2000).

37. Noborio-Hatano, K. et al. Bortezomib overcomes cell-adhesion-mediated drug resistance through downregulation of VLA-4 expression in multiple myeloma. Oncogene 28, 231-242

38. Yanamandra, N. et al. Tipifarnib and bortezomib are synergistic and overcome cell adhesion-mediated drug resistance in multiple myeloma and acute myeloid leukemia. Clin. Cancer Res. 12, 591-599 (2006).

601 39. Ling, S. C. W. et al. Response of myeloma to the proteasome inhibitor bortezomib is 
medRxiv preprint doi: https://doi.org/10.1101/2019.12.16.19015024; this version posted December 19, 2019. The copyright holder for this preprint (which was not certified by peer review) is the author/funder, who has granted medRxiv a license to display the preprint in perpetuity.

It is made available under a CC-BY-NC-ND 4.0 International license .

602

correlated with the unfolded protein response regulator XBP-1. Haematologica 97, 64-72

603 (2012).

604

40. Zhan F, Huang Y, Colla S, Stewart JP et al. The molecular classification of multiple

605 myeloma. Blood 2006 Sep 15;108(6):2020-8. GEO Accession ID GSE2658

606

41. Broyl A, Hose D, Lokhorst $H$, de Knegt $Y$ et al. Gene expression profiling for molecular classification of multiple myeloma in newly diagnosed patients. Blood 2010 Oct

608 7;116(14):2543-53. GEO Accession ID GSE19784

609

42. Johnson, W. E., Li, C. \& Rabinovic, A. Adjusting batch effects in microarray expression data using empirical Bayes methods. Biostatistics 8, 118-127 (2007).

612 Declarations

613 Ethics approval

614

615 Not applicable

616

\section{Consent for publication}

623 The datasets supporting the conclusions of this article are available on GEO. Gene expression

624 data from the HOVON-65/GMMG-HD4 study is available at GSE19784

625 (https://www.ncbi.nlm.nih.gov/geo/query/acc.cgi?acc=GSE19784). Gene expression data from

626 both Total Therapy 2 and Total Therapy 3 are available at GSE2658 
medRxiv preprint doi: https://doi.org/10.1101/2019.12.16.19015024; this version posted December 19, 2019. The copyright holder for this preprint (which was not certified by peer review) is the author/funder, who has granted medRxiv a license to display the preprint in perpetuity.

It is made available under a CC-BY-NC-ND 4.0 International license .

627 (https://www.ncbi.nlm.nih.gov/geo/query/acc.cgi?acc=GSE2658) . 30 patients from the Total

628 Therapy 3 study used in the manuscript are not included in the GSE2658 dataset, these can be

629 found in ArrayExpress dataset E-TABM-1138

630 (https://www.ebi.ac.uk/arrayexpress/experiments/E-TABM-1138/). The PFS survival data for all

631 three studies are available at https://github.com/jubels/GESTURE, linked to the GEO and

632 ArrayExpress IDs. All gene expression and survival data for the CoMMpass study is available at

633 research.themmrf.org

634

635 All code needed to discover and validate the signature is available at

636 https://github.com/jubels/STLsig. All code requires $\mathrm{R}$ and is platform independent.

J.U. and M.H.v.V are employed by SkylineDx. J.d.R. is co-founder of Cyclomics B.V. P.S

641 served on an advisory board to SkylineDx.

\section{Author contributions}

644

J.d.R., M.H.v.V., and J.U. developed the algorithm. J.U. implemented the algorithm and performed data analysis. J.d.R. and J.U. wrote the manuscript. M.H.v.V and P.S. provided

647 comments and edits. All authors discussed the results.

\section{Acknowledgements}

649

650 The CoMMpass dataset was generated as part of the Multiple Myeloma Research

651 Foundation Personalized Medicine Initiatives (https://research.themmrf.org and

652 www.themmrf.org).

653

654

655 
medRxiv preprint doi: https://doi.org/10.1101/2019.12.16.19015024; this version posted December 19, 2019. The copyright holder for this preprint (which was not certified by peer review) is the author/funder, who has granted medRxiv a license to display the preprint in perpetuity.

It is made available under a CC-BY-NC-ND 4.0 International license .

656

657

\section{Figure legends}

\section{Calculate correlations per gene pair}

\section{Fold $A+B(n=404)$}

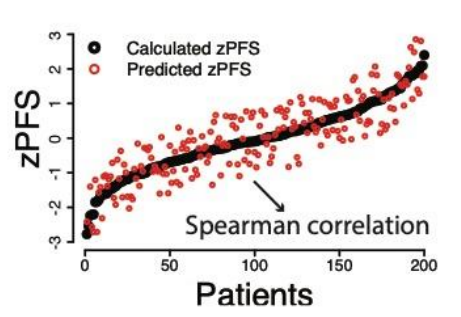

Construct network and extract connected components

\section{Perform forward feature selection}

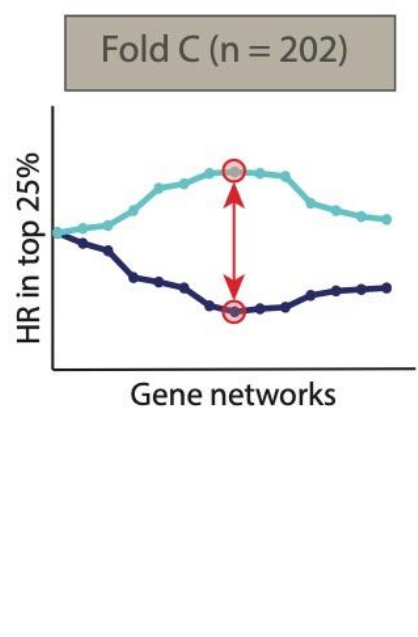

Figure 1. Overview of the construction and selection of the gene networks. First each gene pair 661

662

663

664

665

666

667 is scored on the correlation between predicted and calculated zPFS. Gene networks are then formed by connecting synergistic genes, i.e. genes that are amongst the top $5 \%$ partners for each other based on correlation coefficient. The gene networks are then ranked based on difference between Cox regression $\beta$ in class 'benefit' and 'no benefit'. The signature consists of the combination of gene networks that results in the largest difference in Cox' regression $\beta$ between class 'benefit' and 'no benefit'.
Distribution correlation predicted and calculated zPFS

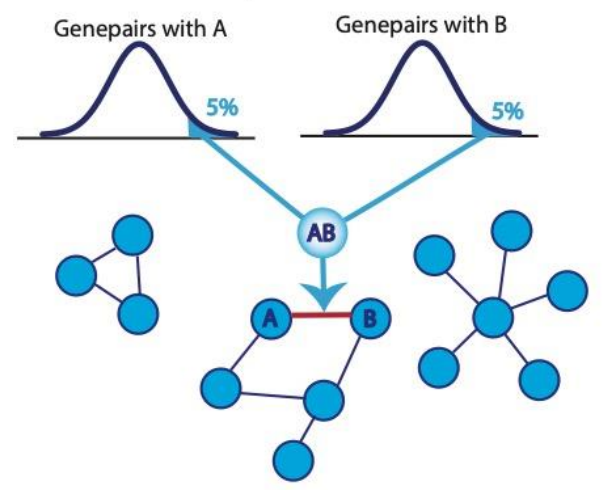




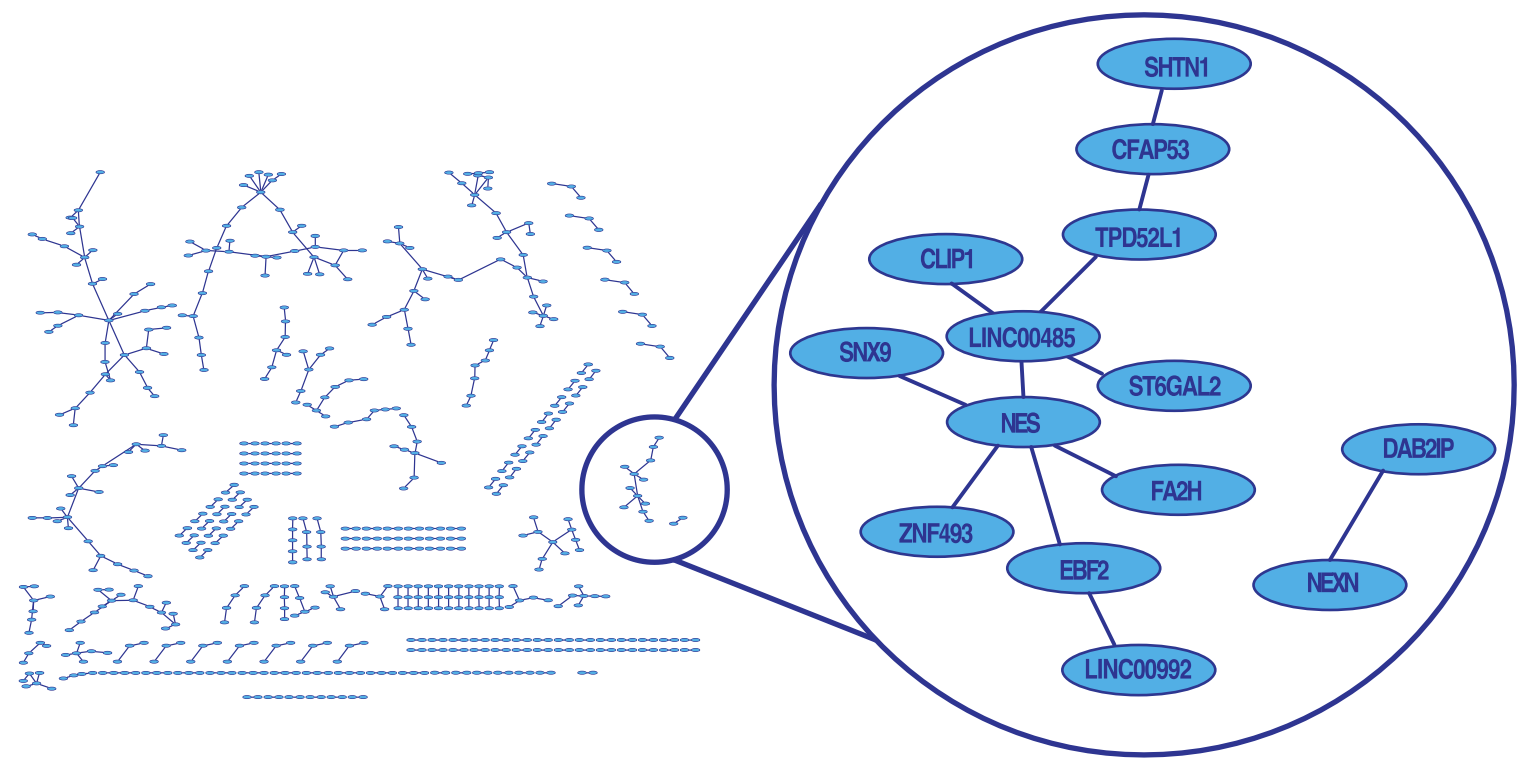

672 Figure 2. The constructed network with all gene networks. The highlighted networks are those

673 selected by the feature selection procedure and contain the 14 genes in the signature

674

675 

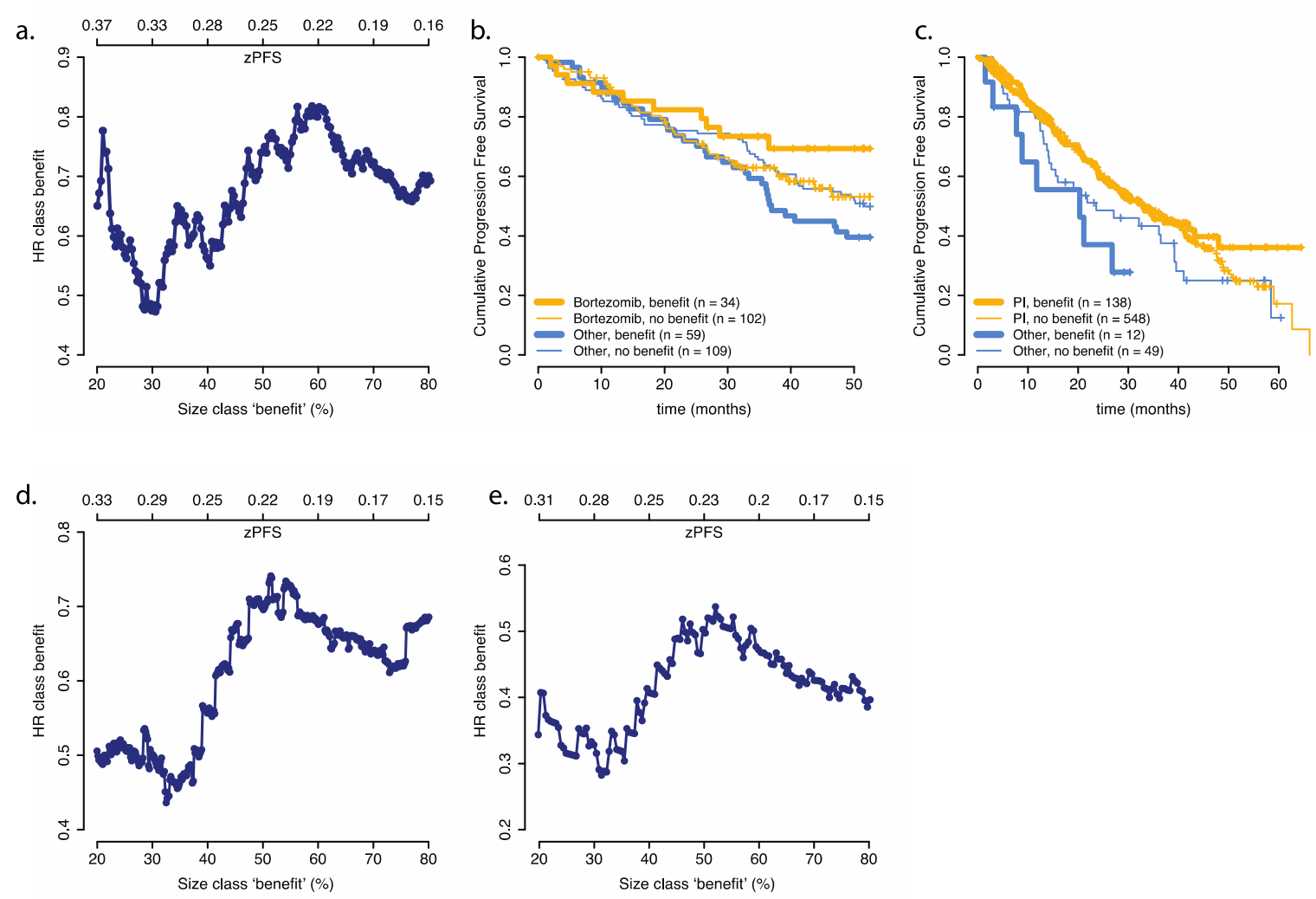

676

677

678

679

680

681

682

683
Figure 3. a. HR found in class 'benefit' using different zPFS thresholds on the hold out data. b. KM of bortezomib benefit prediction in the hold out data using the optimal zPFS threshold. c. KM of PI benefit prediction on CoMMpass using the optimal zPFS threshold from the hold out data. $d$. HR found in class 'benefit' for bortezomib in CoMMpass, using different zPFS thresholds. e. HR found in class 'benefit' for carfilzomib in CoMMpass, using different zPFS thresholds. 
a.

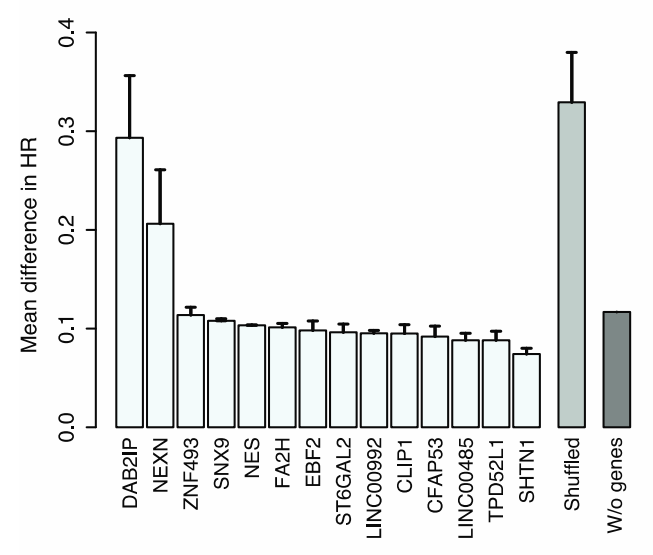

b.

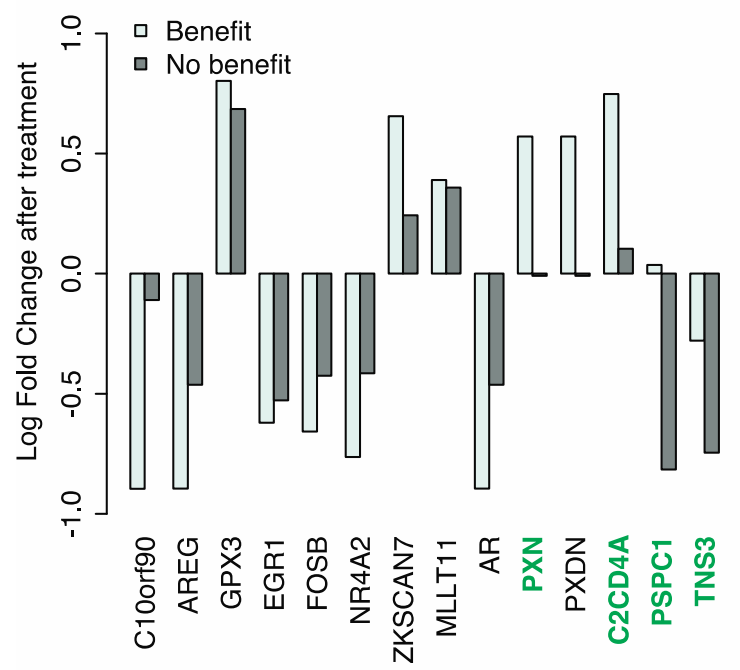

684

685

686

687

688

689

690

691

692

693

694
Figure 4. a. The decrease in performance (difference in HR) for i) shuffling of each gene separately, ii) shuffling links in the network and iii) when the 14 signature genes are excluded from the analysis. Error bars indicate standard error. b. Genes with a significant change in expression before and 48 hours after bortezomib treatment in only either class 'benefit' or 'no benefit'. Genes in green have a significant difference in response between class 'benefit' and 'no benefit', determined empirically by testing the difference with 1000 random labellings. 
medRxiv preprint doi: https://doi.org/10.1101/2019.12.16.19015024; this version posted December 19, 2019. The copyright holder for this preprint (which was not certified by peer review) is the author/funder, who has granted medRxiv a license to display the preprint in perpetuity.

It is made available under a CC-BY-NC-ND 4.0 International license .

695

Supplementary Figure 1

696

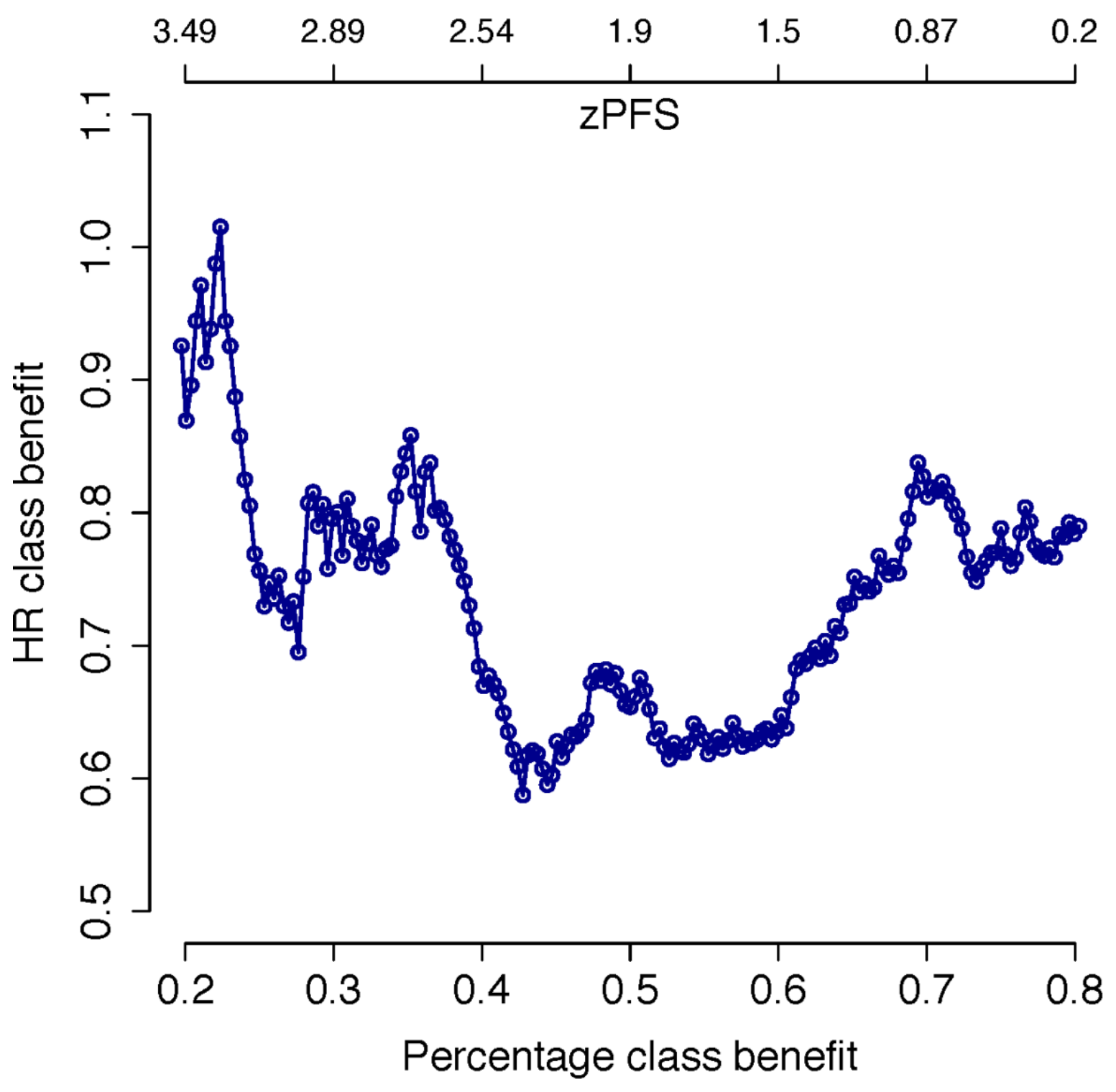

697

698

Supplementary figure 1 . The HR found in class 'benefit' using different cutoffs for $\mathrm{zPFS}$, as predicted by the signature found when excluding the original 14 genes from the analysis. 
medRxiv preprint doi: https://doi.org/10.1101/2019.12.16.19015024; this version posted December 19, 2019. The copyright holder for this preprint (which was not certified by peer review) is the author/funder, who has granted medRxiv a license to display the preprint in perpetuity.

It is made available under a CC-BY-NC-ND 4.0 International license .

700

701

\section{Supplementary figure 2}

\section{Before ComBat}

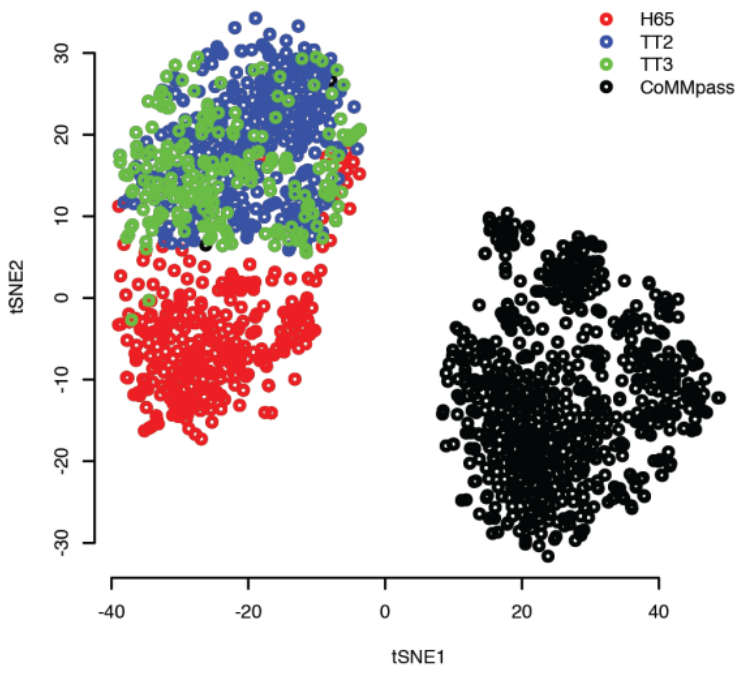

After ComBat

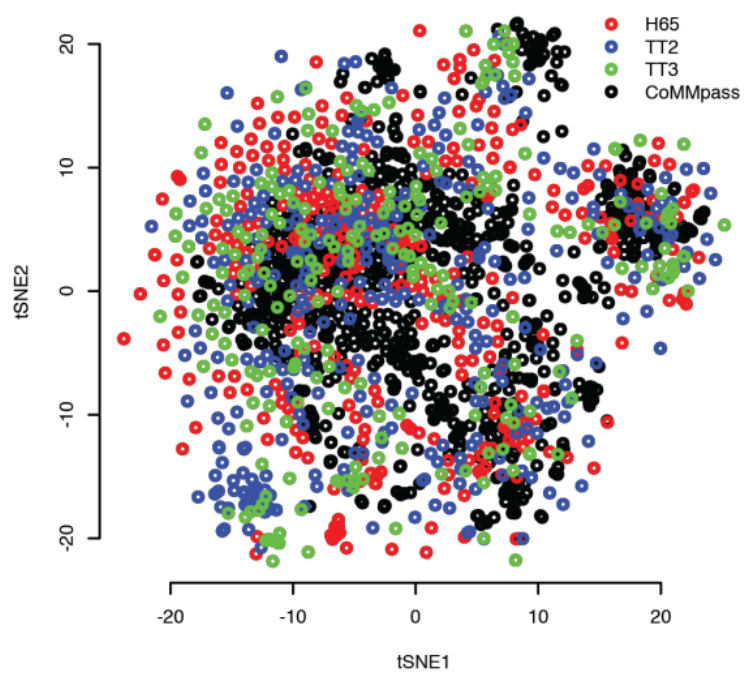

702

Supplementary figure 2. tSNE of the datasets before and after batch correction with ComBat

703

704

705

706 
medRxiv preprint doi: https://doi.org/10.1101/2019.12.16.19015024; this version posted December 19, 2019. The copyright holder for this preprint (which was not certified by peer review) is the author/funder, who has granted medRxiv a license to display the preprint in perpetuity.

It is made available under a CC-BY-NC-ND 4.0 International license .

707

708

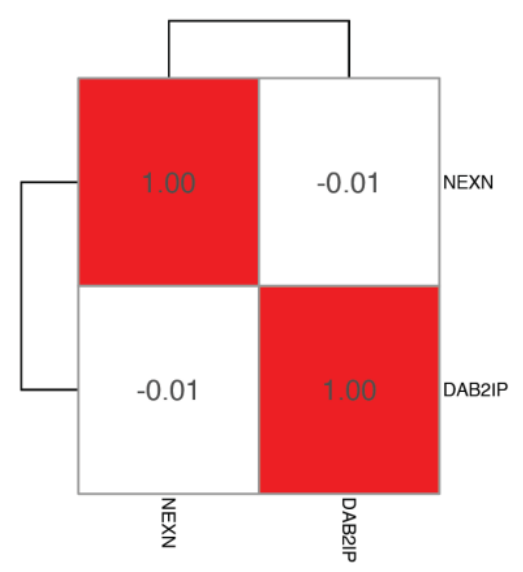

Supplementary figure 3. Correlation matrix of the Pearson correlation between the gene expression of the genes included in the signature, per gene network. 
medRxiv preprint doi: https://doi.org/10.1101/2019.12.16.19015024; this version posted December 19, 2019. The copyright holder for this preprint (which was not certified by peer review) is the author/funder, who has granted medRxiv a license to display the preprint in perpetuity.

It is made available under a CC-BY-NC-ND 4.0 International license .

713

714 Supplementary table $1 \log 2$ fold difference of signature genes between class 'benefit' and 'no

715 benefit' in fold D of the HTT cohort

716

\begin{tabular}{|c|c|c|}
\hline & $\begin{array}{l}\text { Mean } \log 2 \text { fold } \\
\text { difference }\end{array}$ & p-value \\
\hline NEXN & 0.27 & 0.16 \\
\hline DAB2IP & -0.65 & 0.002 \\
\hline CFAP53 & -0.06 & 0.72 \\
\hline TPD52L1 & 0.20 & 0.34 \\
\hline SHTN1 & 0.38 & 0.05 \\
\hline ZNF493 & -0.015 & 0.95 \\
\hline NES & 0.10 & 0.77 \\
\hline CLIP1 & 0.23 & 0.26 \\
\hline $\begin{array}{l}\text { LINC0048 } \\
5\end{array}$ & 0.15 & 0.49 \\
\hline ST6GAL2 & 0.26 & 0.14 \\
\hline EBF2 & -0.14 & 0.44 \\
\hline $\begin{array}{l}\text { LINCO099 } \\
2\end{array}$ & 0.15 & 0.44 \\
\hline FA2H & 0.05 & 0.74 \\
\hline SNX9 & -0.006 & 0.98 \\
\hline
\end{tabular}

717 